\title{
Leaf water potential for surface and subsurface drip irrigated bell pepper under various deficit irrigation strategies
}

\author{
Yesim Bozkurt Colak ${ }^{1^{*}}$
}

\begin{abstract}
${ }^{1}$ Alata Horticultural Research Institute, Soil and Water Resources Research Unit, P.O. Box 23 33400, Tarsus-Mersin, Turkey. "Corresponding author (yesimcolak@ymail.com).
\end{abstract}

Received: 16 February 2021; Accepted: 8 July 2021; doi:10.4067/S0718-58392021000400491

\begin{abstract}
Increased water scarcity necessitates the implementation of water-conserving irrigation management practices to sustain crop production, especially in water-limited areas. Field experiments were conducted to evaluate midday leaf water potential (LWP) of bell pepper (Capsicum аппиит L. var. аппиит) irrigated differentially using surface drip (DI) and subsurface drip irrigation (SDI) systems during 2016 and 2017 growing seasons in the eastern Mediterranean environmental conditions. The treatments considered were deficit irrigations $\left(\mathrm{I}_{50}, \mathrm{I}_{75}\right)$, regulated deficit irrigation (RDI), partial root-zone drying $\left(\mathrm{PRD}_{50}\right)$ and full irrigation $\left(\mathrm{I}_{100}\right)$ under DI and SDI systems. The experimental design was completely randomized in a split-plot system with four replicates per treatment. Deficit irrigation treatments of $\mathrm{I}_{75}$ and $\mathrm{I}_{50}$ received $75 \%$ and $50 \% \mathrm{I}_{100}$, respectively; RDI was supplied with $50 \% \mathrm{I}_{100}$ during vegetative growth stage until flowering, then received $100 \%$ of crop water requirement; $\mathrm{PRD}_{50}$ plots received $50 \% \mathrm{I}_{100}$. Bell pepper plant water status was estimated by LWP. Higher LWP values were determined in $\mathrm{I}_{100}$ for two drip systems than the $\mathrm{I}_{75}, \mathrm{I}_{50}$, and $\mathrm{PRD}_{50}$; LWP correlated significantly $(\mathrm{P}<0.01)$ and negatively with fresh pepper yield, DM yield, leaf area index (LAI), and mean soil water content and all these relations are best described with the curvilinear equations. In conclusion, bell pepper should be irrigated at mean LWP values between -0.89 and $-0.95 \mathrm{MPa}$ without any yield reduction. It is also concluded that RDI and $\mathrm{I}_{75}$ treatments appear to be good alternatives to $\mathrm{I}_{100}$ for sustainable bell pepper production under the Mediterranean environmental conditions.
\end{abstract}

Key words: Bell pepper, Capsicum аппиит, leaf water potential, partial root-zone drying, regulated deficit irrigation.

\section{INTRODUCTION}

Water scarcity is the main factor limiting crop production in the arid and semi-arid environments particularly in the Mediterranean region. The scarce fresh water resources and irregular and uneven distribution of precipitation and climate change imposes significant effect on the sustainability of agriculture in these areas. Therefore, efficient management of irrigation water in an era of water scarcity is necessary, and should aim at saving water and at maximizing its productivity (Yazar and Ince Kaya, 2014; Shammout et al., 2018). Applying water-saving strategies and technologies such as lowpressure irrigation systems like surface and subsurface drip systems along with scientific irrigation scheduling techniques based on plant and soil water status will reduce water consumption of crops. Conventional deficit, partial root-drying (PRD) and regulated deficit irrigation (RDI) are among these strategies developed for irrigation management under water scarcity conditions. The aim of deficit irrigation practices is to maintain soil water at a level that does not significantly reduce crop yield while not completely filling the crop root-zone depth of soil (Chai et al., 2016). The PRD is a deficit irrigation technique in which opposite parts of the plant root system is alternately wetted and dried (Bozkurt Colak et al., 2017); and RDI has been developed recently as an important water-saving strategy in irrigated agriculture. Under RDI 
crops are allowed to sustain some degree of water deficit in less sensitive growth stages and yield reduction, and it is considered an optimizing strategy (Chartzoulakis and Maria, 2015; Chai et al., 2016).

Proper irrigation scheduling with low-pressure systems such as surface drip and subsurface drip has the potential to save water and increase yield, quality as well as water productivity. It is well documented that irrigation methods affect the crop performance, including yield, quality and water productivity (Bozkurt Colak et al., 2018; Evett et al., 2019). Lamm and Rogers (2017) described the subsurface drip (SDI), which has been proven to be an efficient irrigation method with potential advantages of high-water use efficiency, efficient fertilizer application, and lower labour costs than in a conventional drip irrigation system.

Water stress can be very critical for yield response during particular plant growth stage. Therefore, reliable estimation of plant water stress is of paramount importance for the efficient irrigation scheduling. Plant water potential is the suction pressure or the negative pressure necessary for the plant to extract water from the soil. To maintain a continuous water flow through the xylem from the roots to the leaves, where it is transpired through the stomata, the water potential inside the different parts of the plant needs to be lower than the soil water potential. If the quantity of available soil water decreases, the plant decreases its water potential to ensure water supply for photosynthesis, vegetative and generative growth. Plant water potential is thus a good proxy for plant available soil water and to assess water stress of the plant (Rienth and Scholasch, 2019). Therefore, leaf water potential (LWP), which is a direct indicator of plant water status, can be used for irrigation scheduling in the crop production (Bozkurt Colak et al., 2017). For an efficient irrigation scheduling, it is of paramount importance that irrigation should be applied before the plant water stress reaches to a detrimental level. Hence, there is a need to determine the threshold values of plant water stress at which irrigation can be initiated (Parkash and Singh, 2020). Among the possible measures of plant water status include direct measurements of some aspect of such as LWP (Shackel et al., 2010; Ismail, 2012; Bozkurt Colak et al., 2017; Demir et al., 2018; Mohawesh, 2018; Sezen et al., 2019) as well as measurements of a number of plant processes that are known to respond sensitively to water deficits.

Bell pepper (Capsicum аппиит L. var. аппиит) is one of the most important vegetable crops produced under irrigated agriculture. Bell pepper has been classified as susceptible to water stress, with flowering growth stage being the most sensitive period (Yahaya et al., 2012). Such sensitivity has been noticed in several researches that studied the fresh and DM yield reduction affected by water stress (Ferrara et al., 2011; Zotarelli et al., 2011; Sezen et al., 2019; Abdelkhalik et al., 2020). The Mediterranean climate is characterized by mild and rainy winters, and dry and hot summers, with highly variable rainfall distribution, therefore, irrigation is essential for crop production (Galindo et al., 2018).

This study was carried out because limited information is available on bell pepper's physiological response such as LWP along with yield response to regulated deficit irrigation (RDI), partial root-zone drying (PRD) and conventional deficit irrigation applied with subsurface drip irrigation systems. Therefore, the main objectives of this study were to investigate yield and physiological response of field grown bell pepper using LWP to various deficit irrigation regimes such as RDI, PRD, and conventional deficit and full irrigation applied with surface drip and subsurface drip systems and to determine the optimal threshold levels for LWP for irrigation initiation for bell pepper in the eastern Mediterranean environmental conditions.

\section{MATERIALS AND METHODS}

\section{Experimental site and soil}

Two-year field experiments were carried out at the Soil and Water Resources Unit of Alata Horticultural Research Institute $\left(36^{\circ} 53^{\prime} \mathrm{N}, 34^{\circ} 57^{\prime} \mathrm{E} ; 30.0 \mathrm{~m}\right.$ a.s.1.), in Tarsus in the eastern Mediterranean region of Turkey during 2016 and 2017 growing seasons. In the study area typical Mediterranean climatic conditions prevail. The mean annual rainfall is $616 \mathrm{~mm}$ and more than half of the rainfall is received in the period covering months of November through May. The mean annual evaporation from Class A pan is $1487 \mathrm{~mm}$, average annual temperature is $17.8^{\circ} \mathrm{C}$ with mean humidity of $71.0 \%$ (MGM, 2019). The study years along with long term mean climatic data from 1950 to 2019 are summarized in Table 1 . The soil of experimental site is classified as Arikli silty-clay-loam texture with relatively high-water holding capacity (116 $\mathrm{mm}$ in the 60 $\mathrm{cm}$ soil depth) and has a $\mathrm{pH}$ range of 7.91-8.11, electrical conductivity of the saturation extract (ECe) $0.91-1.03 \mathrm{dS} \mathrm{m}^{-1}$, and volumetric soil water contents at field capacity and permanent wilting point of the root-zone $41.3 \%-43.9 \%$ and $20.9 \%$ $25.7 \%$, respectively. Average bulk density values varied between 1.30 and $1.45 \mathrm{~g} \mathrm{~cm}^{-3}$. 
Table 1. Historical monthly mean and 2016-2017 growing seasons climatic data of the experimental area.

\begin{tabular}{llrrrrrr}
\hline Years & Climatic parameters & March & April & May & June & July & August \\
\hline 2016 & Tmax, ${ }^{\circ} \mathrm{C}$ & 21.4 & 26.8 & 26.3 & 31.0 & 32.9 & 34.4 \\
& Tmin, ${ }^{\circ} \mathrm{C}$ & 9.5 & 12.1 & 15.2 & 20.2 & 23.5 & 23.5 \\
& Tmean, ${ }^{\circ} \mathrm{C}$ & 15.0 & 19.2 & 20.3 & 25.5 & 28.0 & 28.4 \\
& Rainfall, mm & 77.6 & 2.2 & 41.8 & 32.0 & 0.0 & 5.8 \\
& Evaporation, mm & 112.4 & 141.7 & 145.5 & 183.1 & 220.7 & 200.9 \\
& RH, $\%$ & 60.7 & 58.6 & 75.5 & 74.3 & 75.3 & 74.0 \\
& Wind speed, $\mathrm{m} \mathrm{s}^{-1}$ & 2.4 & 2.0 & 2.1 & 1.8 & 2.0 & 1.9 \\
\hline 2017 & Tmax, ${ }^{\circ} \mathrm{C}$ & 23.7 & 26.6 & 30.2 & 34.2 & 33.7 & 34.8 \\
& Tmin, ${ }^{\circ} \mathrm{C}$ & 11.6 & 15.0 & 19.5 & 23.4 & 23.4 & 23.6 \\
& Tmean, ${ }^{\circ} \mathrm{C}$ & 17.6 & 20.5 & 24.7 & 28.5 & 28.1 & 28.6 \\
& Rainfall, mm & 103.8 & 14.8 & 2.2 & 0.2 & - & - \\
& Evaporation, mm & 128.3 & 153.8 & 208.4 & 204.7 & 201.8 & 211.3 \\
& RH, $\%$ & 64.9 & 73.3 & 75.3 & 74.2 & 75.3 & 74.1 \\
& Wind speed, $\mathrm{m} \mathrm{s}^{-1}$ & 2.3 & 2.1 & 1.9 & 1.9 & 1.8 & 1.9 \\
\hline Long-term & Tmax, ${ }^{\circ} \mathrm{C}$ & 20.0 & 24.3 & 28.0 & 31.1 & 32.5 & 33.0 \\
$(1950-2019)$ & Tmin, ${ }^{\circ} \mathrm{C}$ & 6.7 & 10.4 & 14.6 & 18.5 & 21.2 & 21.0 \\
& Tmean, ${ }^{\circ} \mathrm{C}$ & 12.7 & 16.8 & 20.9 & 24.5 & 26.8 & 27.1 \\
& Rainfall, mm & 58.9 & 38.9 & 30.3 & 11.1 & 3.6 & 2.2 \\
& Evaporation, mm & 88.9 & 119.7 & 167.7 & 199.5 & 216.7 & 197.7 \\
& RH, $\%$ & 70.0 & 71.4 & 70.9 & 71.8 & 75.3 & 75.0 \\
\hline
\end{tabular}

Tmax: Maximum air temperature; Tmin: minimum air temperature; Tmean: mean air temperature; RH: relative humidity.

\section{Experimental design and irrigation treatments}

The experimental design was randomized blocks in split-plots with four replicates. The experimental treatments consisted of two irrigation techniques namely surface drip (DI) and subsurface drip systems (SDI), five irrigation strategies designated as full irrigation ( $\mathrm{I}_{100}$ ), deficit irrigation $\mathrm{I}_{50}$, deficit irrigation $\mathrm{I}_{75}$, partial root-zone drying $\left(\mathrm{PRD}_{50}\right)$, and regulated deficit irrigation (RDI). The two irrigation systems (surface drip and subsurface drip) were assigned to the main plots, irrigation strategies were assigned to the sub plots. Full irrigation $\left(\mathrm{I}_{100}\right)$ was delivered when $25 \%$ of available water in the effective root-zone depth of $40 \mathrm{~cm}$ was depleted and replenished to field capacity. Treatment RDI received 50\% $\mathrm{I}_{100}$ until flowering growth stage, there upon received $100 \%$ water requirement until harvest the same as $\mathrm{I}_{100}$. Conventional deficit irrigation treatments $\mathrm{I}_{75}$ and $\mathrm{I}_{50}$ received $75 \%$ and $50 \% \mathrm{I}_{100}$, respectively, throughout the growing season $\mathrm{PRD}_{50}$ plots received $50 \% \mathrm{I}_{100}$, but from the alternative drip laterals in each application. Dimensions of each subplot were $10 \mathrm{~m} \times 3.5 \mathrm{~m}$ (five plant rows).

\section{Drip irrigation systems}

Two drip systems were used in the study. Polyethylene (PE) laterals with diameter of $16 \mathrm{~mm}$ with in-line emitters spaced $0.33 \mathrm{~m}$ apart, flow rate of $2.0 \mathrm{~L} \mathrm{~h}^{-1}$ at an operating pressure of $100 \mathrm{kPa}$ in the surface drip irrigation plots (DI). A drip lateral line was laid in the bell plant rows of $0.70 \mathrm{~m}$ in the experimental plots. In $\mathrm{PRD}_{50}$ plots, two drip laterals were placed on both sides of the crop row at $15 \mathrm{~cm}$ away from the center of plant row. In $\mathrm{PRD}_{50}$ plots one lateral supplied water during one irrigation, the other lateral provided water in the next irrigation. A locally produced surface drip-irrigation system (Betaplast Comp., Adana, Turkey) was used in the study.

In the subsurface drip system (SDI), drip lateral lines were placed under $20 \mathrm{~cm}$ of the soil surface in shallow furrows made by a chisel plow. In SDI treatment plots, in-line emitters with flow rate of $2.0 \mathrm{~L} \mathrm{~h}^{-1}$ and spaced at $33 \mathrm{~cm}$ intervals on the lateral line made of PE were used (Geoflow Corte Madera, California, USA). Both drip irrigation systems were installed in the experimental plots several days before the transplantation of bell pepper (Capsicum anпиит L. var. аппиит) seedlings.

\section{Agronomic practices}

In this study, 'Zafer' bell pepper was used, and $21 \mathrm{~d}$ old seedlings were transplanted into the experimental plots with row spacing of $70 \mathrm{~cm}$ and in-row plant spacing of $20 \mathrm{~cm}$ on 19 April 2016 and 11 April 2017. Just before the bell pepper 
seedlings transplanted in the trial plots, a compound fertilizer of $50 \mathrm{~kg} \mathrm{~N} \mathrm{ha}^{-1}, 50 \mathrm{~kg} \mathrm{P}_{2} \mathrm{O}_{5}$ ha $^{-1}$, and $50 \mathrm{~kg} \mathrm{~K}_{2} \mathrm{O} \mathrm{ha}^{-1}(15 \%$ $15 \%-15 \% \mathrm{~N}-\mathrm{P}_{2} \mathrm{O}_{5}-\mathrm{K}_{2} \mathrm{O}$ ) was applied to the band in the plant rows and incorporated into the soil. Starting 3 wk after planting, the remaining amount of $\mathrm{N}$ was applied to the plots by fertigation by dissolving $1.25 \mathrm{~kg}$ urea $(46 \% \mathrm{~N})$ in water at fertilizer tank at each irrigation. All plots received $164 \mathrm{~kg} \mathrm{~N}$ ha-1 $^{-1}$ by means of fertigation. The total amount of $\mathrm{N}$ applied to all plots was $214 \mathrm{~kg} \mathrm{ha}^{-1}$.

\section{Measurements and observations}

Weather data including rainfall, maximum and minimum air temperatures, air humidity, wind speed and solar radiation, collected from an automatic recording meteorological station located at the experimental site on a daily basis for the study years along with long-term mean climatic data from 1950 to 2019, are summarized in Table 1.

Plant observations and soil water content measurements were initiated just after transplanting, and terminated on the final harvest date. Soil water content was monitored at traditional (gravimetric) $0-60 \mathrm{~cm}$ soil depth. Soil-water content was determined with gravimetric sampling method at 0-20,20-40, and 40-60 $\mathrm{cm}$ soil layers $1 \mathrm{~d}$ before irrigations until harvest in four replicates in full irrigation treatment plots. In other treaments, soil water content (SWC) measurements made $1 \mathrm{~d}$ before every other irrigation.

The volume of irrigation water applied to the full irrigation plots under both drip systems was calculated with the following equation:

$$
\mathrm{V}=\mathrm{SWD} \times \mathrm{A} \times \mathrm{P}
$$

where $\mathrm{V}$ is the volume of irrigation water $(\mathrm{L}), \mathrm{SWD}$ is the soil water deficit in the experimental plots $(\mathrm{mm})$, $\mathrm{A}$ is plot area $\left(\mathrm{m}^{2}\right)$, and $\mathrm{P}$ is the plant cover percentage (wetted area) (\%). In full irrigation plots, SWD corresponded to approximately $25 \%$ available water in $40 \mathrm{~cm}$ depth of soil; and all treatment plots were irrigated simultaneously. Wetted percentage in each treatment plot was estimated by measuring crop cover percentage just before an irrigation application. The amount of water applied to other treatments was calculated with reference to $I_{100}$. The duration of water delivery to each treatment plot was controlled with gate valves at the inlet of each manifold.

Seasonal crop water use or actual evapotranspiration (ETa) of bell pepper was estimated with the water balance equation:

$$
\mathrm{ETa}=\mathrm{P}+\mathrm{I}-\mathrm{Dp}-\mathrm{Ro} \pm \Delta \mathrm{S}
$$

where ETa is actual evapotranspiration $(\mathrm{mm}), \mathrm{P}$ is rainfall $(\mathrm{mm}), \mathrm{I}$ is the quantity of irrigation water applied $(\mathrm{mm}), \Delta \mathrm{S}$ is the change in the soil water storage in $60 \mathrm{~cm}$ soil depth at planting and at harvest ( $\mathrm{mm}$ ), Dp is deep percolation losses below the root-zone depth $(\mathrm{mm})$, and Ro is runoff from the experimental plots $(\mathrm{mm})$. Rainfalls greater than the soil water deficit in $60 \mathrm{~cm}$ soil depth is considered as deep percolation.

Midday leaf water potential (LWP) was measured with a pressure chamber (model 615, PMS Instrument Company, Albany, Oregon, USA) $1 \mathrm{~d}$ before the irrigations throughout the growing season; measurements were taken between 12:00 and 14:00 h, on two fully developed sunlit leaves of a pepper plant per experimental unit and the average of two measurements is taken as the mean midday LWP value for each plot.

Bell pepper water productivity (WP) and irrigation water productivity (IWP) were calculated using the following equations (Bozkurt Colak et al., 2018):

$$
\begin{gathered}
\mathrm{WP}=\mathrm{Y} / \mathrm{ETa} \\
\mathrm{IWP}=\mathrm{Y} / \mathrm{I}
\end{gathered}
$$

where WP is water productivity $\left(\mathrm{kg} \mathrm{m}^{-3}\right), \mathrm{Y}$ is yield of irrigated treatment $\left(\mathrm{kg} \mathrm{ha}^{-1}\right)$, ETa is actual evapotranspiration $(\mathrm{mm})$, IWP is irrigation water productivity $\left(\mathrm{kg} \mathrm{m}^{-3}\right)$ and I is irrigation water applied $(\mathrm{mm})$.

Bell pepper yields were determined by hand harvesting all the plants within the $6 \mathrm{~m}$ sections of the three adjacent centre rows in each plot depending on the physiological maturity of plants. The harvest area in each plot was $12.6 \mathrm{~m}^{2}$ (three rows, each $6 \mathrm{~m}$ long). Bell peppers were harvested five times each growing season. Above ground DM yield was determined by cutting all pepper plants within a $1.0 \mathrm{~m}$ row section per plot at ground level at 2-wk intervals until harvest. Plant samples were dried at $65^{\circ} \mathrm{C}$ until constant weight was achieved.

Leaf area index (LAI) measurements were made at 2-wk intervals throughout the growing season in the central two rows of bell pepper plants in each treatment using a plant canopy analyzer (LAI-2000, Li-COR, Lincoln, Nebraska, USA). Four measurements below the canopy and one measurement above the canopy were made to account for the canopy light 
interception at five different angles, from which LAI was computed using a model of radiative transfer in vegetative canopies.

In determining the starting and ending dates of the development periods of the bell pepper plant, it was decided by looking at the plants and the general condition of the plots. Some development periods of the bell pepper plant are given in Table 2 for full irrigation issues. During the study years, the total growing season length was determined as 114 and 122 $\mathrm{d}$ for $\mathrm{I}_{100}$ treatments. The growth period in the second year was $10 \mathrm{~d}$ longer than the first year. The length of the growing season here represents the total time elapsed from transplanting the seedlings in the field to the last harvest.

\section{Statistical analysis}

Data collected were subjected to ANOVA based on the JMP Statistical software developed by SAS (SAS Institute, Cary, North Carolina, USA). Least significant difference (LSD) test was used to compare the treatment means.

\section{RESULTS AND DISCUSSION}

\section{Irrigation and evapotranspiration}

The 2016 growing season climatic conditions were typical of the conditions that prevail in the Mediterranean region. However, the mean air temperatures in 2017 season May through July were several degrees greater than those in 2016 as well as long-term means. Monthly rainfalls fluctuated during and between the two growing seasons (2016 and 2017) when the experiments were conducted. In general, the 2016 growing season was relatively wet with a total rainfall of $81.8 \mathrm{~mm}$ when compared with the 2017 growing season with a total rainfall of $17.2 \mathrm{~mm}$. In 2016, rainfall received in May-June period was also greater than the long-term means.

Irrigation amounts, relative irrigation, seasonal crop water use or actual crop evapotranspiration (ETa), relative ETa, water productivity and irrigation water productivity for the different irrigation strategies under two drip irrigation methods for the experimental years are summarized in Table 3 . All treatments received $35 \mathrm{~mm}$ of irrigation water in two applications in order to establishing uniform plant stand at the beginning of the 2016 growing season. The treatment irrigation program was initiated on 20 June 2016 and the final irrigation was applied on 8 August 2016. In surface (DI) and subsurface drip (SDI) systems, two equal irrigation and 22 treatment irrigation applications were made. The amount of irrigation water in DI plots varied from $335 \mathrm{~mm}$ in $\mathrm{I}_{50}$ and $\mathrm{PRD}_{50}$ to $545 \mathrm{~mm}$ in $\mathrm{I}_{100}$ treatment; the corresponding values for the SDI plots were 307 to $489 \mathrm{~mm}$. In the second year of the field experiment, following the transplanting of the seedlings was completed, an equal amount of $45 \mathrm{~mm}$ irrigation water was applied to all treatments. The treatment irrigation program started on 9 May 2017 and the last irrigation program was implemented on 8 August 2017. In DI and SDI systems, three equal irrigation and 22 treatment irrigation applications were made. The total amount of irrigation water in DI treatment plots varied from $359 \mathrm{~mm}$ in $\mathrm{I}_{50}$ and $\mathrm{PRD}_{50}$ to $647 \mathrm{~mm}$ in $\mathrm{I}_{100}$ treatment; the corresponding values for the SDI treatment plots were 335 to $618 \mathrm{~mm}$. The SDI-I $\mathrm{I}_{100}$ plots received $10 \%$ and $4.5 \%$ less irrigation water as compared to DI-I $\mathrm{I}_{100}$ plots in 2016 and 2017 growing season, respectively, due to reduced surface evaporation losses under SDI. Due to warmer weather conditons prevailed in 2017 growing season, total amount of irrigation water applied to treatments in 2017 were $16 \%$ and $21 \%$ greater in $\mathrm{I}_{100}$ treatment plots under DI and SDI, respectively, than those in 2016. The RDI plots received $5.0 \%$ and $19.3 \%$ less water than $\mathrm{I}_{100}$ plots under DI and SDI, respectively in 2016; the corresponding values were $11.9 \%$ and $9.9 \%$ in 2017.

Table 2. Phenological observation dates during research years.

\begin{tabular}{lcc}
\hline Phenological observations & 2016 & 2017 \\
\hline Planting & 19 April & 11 April \\
Flowering & 2 June & 17 May \\
Fruit set & 12 June & 29 May \\
Harvest 1 & 23 June & 19 June \\
Harvest 2 & 30 June & 4 July \\
Harvest 3 & 11 July & 20 July \\
Harvest 4 & 19 July & 1 August \\
Harvest 5 & 10 August & 11 August \\
\hline
\end{tabular}


Table 3. Different variables of bell pepper crop affected by different irrigation treatments in two experimental years.

\begin{tabular}{|c|c|c|c|c|c|c|c|c|c|}
\hline Years & $\begin{array}{l}\text { Irrigation } \\
\text { systems }\end{array}$ & $\begin{array}{l}\text { Irrigation } \\
\text { regimes }\end{array}$ & $\begin{array}{l}\text { Seasonal } \\
\text { irrigation }\end{array}$ & ETa & Yield & DM yield & LAI & WP & IWP \\
\hline \multirow{11}{*}{2016} & & & $-n$ & $1-$ & $\mathrm{tha}^{-1}$ & $\mathrm{~kg} \mathrm{ha}^{-1}$ & $\mathrm{~m}^{2} \mathrm{~m}^{-2}$ & $-\mathrm{k}$ & ${ }^{-3}-$ \\
\hline & \multirow[t]{5}{*}{ DI } & $\mathrm{I}_{100}$ & 545 & 693 & 75.7 & $8480 \mathrm{a}$ & $4.28 \mathrm{ab}$ & $10.9 \mathrm{~d}$ & $13.9 \mathrm{e}$ \\
\hline & & $\mathrm{I}_{75}$ & 440 & 587 & 67.4 & $7490 d$ & $3.78 \mathrm{c}$ & $11.5 \mathrm{c}$ & $15.3 \mathrm{~d}$ \\
\hline & & $\mathrm{I}_{50}$ & 335 & 492 & 51.3 & $5610 \mathrm{e}$ & $3.68 \mathrm{~d}$ & $10.4 \mathrm{e}$ & $13.4 \mathrm{ef}$ \\
\hline & & $\mathrm{PRD}_{50}$ & 335 & 484 & 45.5 & $5720 \mathrm{e}$ & $3.29 \mathrm{e}$ & $9.4 \mathrm{~g}$ & $15.3 \mathrm{~d}$ \\
\hline & & RDI & 518 & 669 & 69.7 & $8100 \mathrm{~b}$ & $4.24 \mathrm{~b}$ & $10.4 \mathrm{e}$ & $13.6 \mathrm{e}$ \\
\hline & \multirow[t]{5}{*}{ SDI } & $\mathrm{I}_{100}$ & 489 & 635 & 74.2 & $8040 \mathrm{~b}$ & $4.35 \mathrm{a}$ & $11.7 \mathrm{c}$ & $15.2 \mathrm{~d}$ \\
\hline & & $\mathrm{I}_{75}$ & 398 & 548 & 69.4 & $7460 d$ & $3.85 \mathrm{c}$ & $12.7 \mathrm{a}$ & $17.4 \mathrm{~b}$ \\
\hline & & $\mathrm{I}_{50}$ & 307 & 458 & 57.7 & $4670 \mathrm{f}$ & $3.35 \mathrm{e}$ & $12.6 \mathrm{a}$ & $16.1 \mathrm{c}$ \\
\hline & & $\mathrm{PRD}_{50}$ & 307 & 456 & 54.1 & $5710 \mathrm{e}$ & $3.37 \mathrm{e}$ & $11.8 \mathrm{bc}$ & $18.8 \mathrm{a}$ \\
\hline & & RDI & 440 & 618 & 70.6 & $7760 \mathrm{c}$ & $3.89 \mathrm{c}$ & $11.9 \mathrm{~b}$ & $17.6 \mathrm{~b}$ \\
\hline \multirow[t]{10}{*}{2017} & \multirow[t]{5}{*}{ DI } & $\mathrm{I}_{100}$ & 647 & 797 & 70.6 & $6110 \mathrm{~b}$ & 4.15 & 8.9 & 10.9 \\
\hline & & $\mathrm{I}_{75}$ & 506 & 673 & 65.2 & $5080 \mathrm{e}$ & 3.95 & 9.7 & 12.9 \\
\hline & & $\mathrm{I}_{50}$ & 359 & 540 & 46.9 & $4590 \mathrm{~g}$ & 3.14 & 9.4 & 11.9 \\
\hline & & $\mathrm{PRD}_{50}$ & 359 & 529 & 45.4 & $4320 \mathrm{~h}$ & 3.06 & 8.7 & 13.1 \\
\hline & & RDI & 570 & 723 & 67.8 & $5570 \mathrm{~d}$ & 4.05 & 8.6 & 12.6 \\
\hline & \multirow[t]{5}{*}{ SDI } & $\mathrm{I}_{100}$ & 618 & 760 & 71.5 & $7140 \mathrm{a}$ & 4.19 & 9.4 & 11.6 \\
\hline & & $\mathrm{I}_{75}$ & 477 & 634 & 67.7 & $5440 \mathrm{~d}$ & 4.01 & 10.7 & 14.2 \\
\hline & & $\mathrm{I}_{50}$ & 335 & 514 & 54.5 & $4870 f$ & 3.20 & 9.4 & 12.0 \\
\hline & & $\mathrm{PRD}_{50}$ & 335 & 501 & 46.4 & $4610 \mathrm{~g}$ & 3.14 & 10.6 & 16.4 \\
\hline & & RDI & 583 & 744 & 69.8 & $5750 \mathrm{c}$ & 4.11 & 9.3 & 13.9 \\
\hline
\end{tabular}

ETa: Actual crop evapotranspiration; DM: dry matter; LAI: leaf area index; WP: water productivity; IWP: irrigation water productivity; DI: surface drip irrigation; $\mathrm{SDI}$ : subsurface drip irrigation; $\mathrm{I}_{100}$ : full irrigation; $\mathrm{I}_{75}$ : deficit irrigation; $\mathrm{I}_{50}$ : deficit irrigation; PRD: partial root zone drying; RDI: regulated deficit irrigation.

Actual crop evapotranspiration (ETa) values ranged from $484 \mathrm{~mm}$ in $\mathrm{PRD}_{50}$ to $693 \mathrm{~mm}$ in $\mathrm{I}_{100}$ in DI, and varied between $456 \mathrm{~mm}$ in $\mathrm{PRD}_{50}$ and $635 \mathrm{~mm}$ in $\mathrm{I}_{100}$ in SDI plots in 2016 growing season. In 2017, ETa values varied from $529 \mathrm{~mm}$ in PRD $_{50}$ to $797 \mathrm{~mm}$ in $\mathrm{I}_{100}$ in DI plots; and varied between 501 and $760 \mathrm{~mm}$ in SDI plots. In 2016, ETa values in $\mathrm{I}_{75}$ and RDI treatments in DI system were 587 and $669 \mathrm{~mm}$, respectively. The corresponding values for the SDI were 548 and $618 \mathrm{~mm}$, respectively. Regulated deficit irrigation treatments (RDI) used 3.5\% and 10\% less water than $\mathrm{I}_{100}$ in DI and SDI, respectively, in 2016; and corresponding values for 2017 were $11.9 \%$ and 5.7\%. Decreased SWC in $\mathrm{I}_{50}$ and $\mathrm{PRD}_{50}$ treatments resulted in lower ETa values. This occurred because the water content decreased under these treatments resulting in increased abscisic acid concentration triggering stomatal closure as reported by Hashem et al. (2019). The results revealed that the highest and the lowest ranges of water consumption were found in the $\mathrm{I}_{100}$ and $\mathrm{PRD}_{50}$ treatments in both experimental years. Bell pepper plants in $\mathrm{PRD}_{50}$ consumed slightly less water as compared to $\mathrm{I}_{50}$ in both experimental years although these two treatments received the same amount of water. The difference in ETa between the $\mathrm{PRD}_{50}$ and $\mathrm{DI}_{50}$ was most probably due to reduced evaporation losses form the soil surface under $\mathrm{PRD}_{50}$. It was observed that RDI saved 5\% and 12\% water as compared with $\mathrm{I}_{100}$ under DI; and 10\% and 6\% under SDI system, respectively, in the experimental years. Treatment $\mathrm{I}_{75}$ resulted in an average water saving of $20.6 \%$ and $26.7 \%$ for DI and SDI, respectively.

\section{Variation of soil water content}

Variations of soil water content (SWC) in the effective root-zone depth of $60 \mathrm{~cm}$ in the different irrigation treatments under DI and SDI systems are shown in Figures 1a-1d for the 2016 and 2017 experimental years. In general, the trends of variations in SWC during the growing seasons were similar under both drip irrigation systems for the same irrigation treatment. The SWC values differed depending on the amount of irrigation water applied to the treatments. Evidently, the level of SWC immediately decreased in the root zone after deficit irrigation treatments were applied and was less than that in full irrigation treatment. Conversely, the rate of the SWC constantly decreased when plant growth increased and the uptake of water increased. Soil water contents in the $0.60 \mathrm{~m}$ soil depth decreased gradually towards the physiological maturity period in all treatments in 2016 and 2017 growing seasons under both drip systems. The highest SWC were found in $\mathrm{I}_{100}$ treatment plots both under DI and SDI systems; SWC remained above $25 \%$ of available water throughout 
Figure 1. Soil water content $(S W C)$ variation under different treatments in bell pepper field; full irrigation ( $\left.I_{100}\right)$, regulated deficit irrigation (RDI), partial rootzone drying $\left(P R D_{50}\right)$, deficit irrigations $\left(I_{75}\right.$ and $\left.I_{50}\right)$ at $0-60 \mathrm{~cm}$ soil depth in two experimental years.

a)

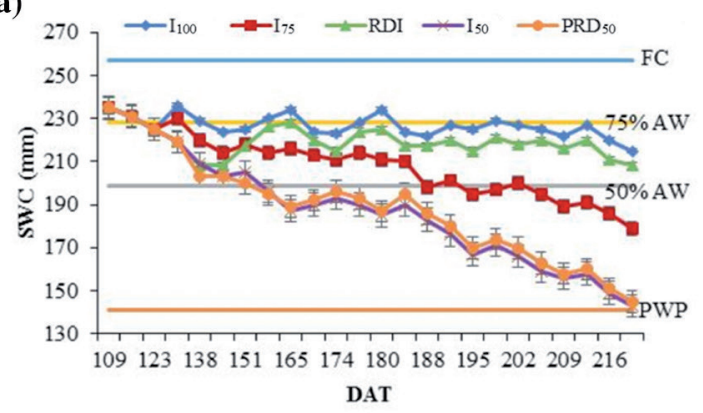

c)

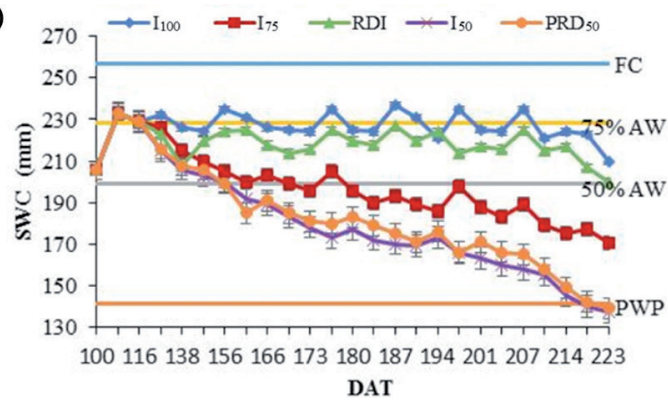

b)

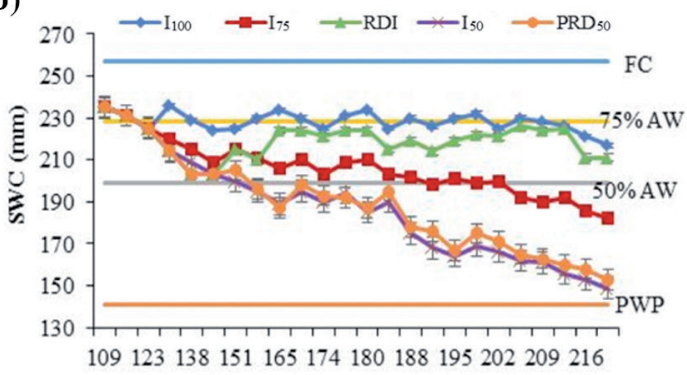

DAT

d)

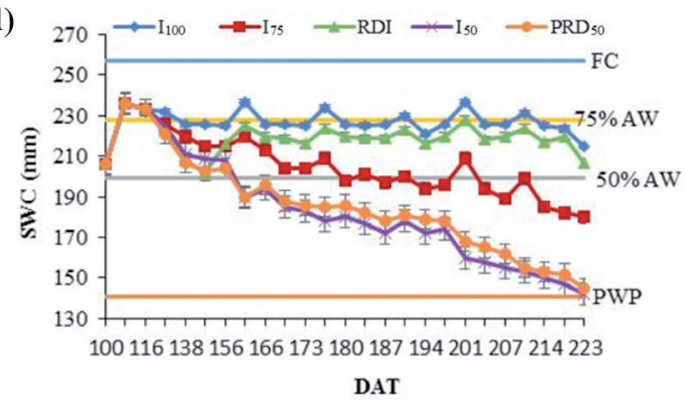

Vertical bars represent standard errors.

(a) SWC in surface drip (DI) in 2016; (b) SWC in subsurface drip irrigation (SDI) in 2016; (c) SWC in DI in 2017; (d) SWC in SDI in 2017.

$\mathrm{I}_{100}$ : Full irrigation; $\mathrm{I}_{75}$ : deficit irrigation $\left(75 \% \mathrm{I}_{100}\right)$; $\mathrm{I}_{50}$ : deficit irrigation $\left(50 \% \mathrm{I}_{100}\right)$; $\mathrm{PRD}_{50}$ : partial root zone drying; RDI: regulated deficit

irrigation; FC: field capacity; AW: available water; PWP: permanent wilting point; DAT: days after transplanting.

both growing seasons except at the end of growing seasons. In RDI plots SWC decreased gradually during vegetative growth stage until flowering since this treatment received $50 \%$ of water that applied to $\mathrm{I}_{100}$ under DI and SDI systems. However, there upon RDI received the same amount of water as $\mathrm{I}_{100}$, therefore $\mathrm{SWC}$ remained just below the $\mathrm{I}_{100}$ treatment throughout the growing season. The SWC in the severe deficit irrigation treatments $\left(\mathrm{I}_{50}\right.$ and $\left.\mathrm{PRD}_{50}\right)$ was found to be below $50 \%$ available water fell during most of the growing seasons. It was observed that soil water values in PRD ${ }_{50}$ plots were slightly higher than the $\mathrm{I}_{50}$ under both drip systems. In $\mathrm{I}_{75}$ plots, SWC remained above 50\% available water until on 192 and $202 \mathrm{~d}$ after transplanting (DAT) for DI and SDI plots in 2016; and corresponding values were 180 and 194 DAT in the 2017 growing season.

\section{Bell pepper yield}

The total bell pepper yield values in five pickings for the different irrigation treatments under two drip irrigation methods for both experimental years (2016 and 2017) are presented in Table 3. The statistical analysis of the parameters considered in this study, summarized in Table 4 and Figure 2a, shows comparison of yield values averaged over two drip systems for the different treatments in the experimental years. Yields varied from $45.5 \mathrm{t} \mathrm{ha}^{-1}$ in $\mathrm{PRD}_{50}$ to $75.7 \mathrm{tha}^{-1}$ in $\mathrm{I}_{100}$ in DI system; and changed between $54.1 \mathrm{t} \mathrm{ha}^{-1}$ in $\mathrm{PRD}_{50}$ and $74.2 \mathrm{t} \mathrm{ha}^{-1}$ in $\mathrm{I}_{100}$ under SDI system in 2016. In 2017, yields ranged from $45.4 \mathrm{t} \mathrm{ha}^{-1}$ in $\mathrm{PRD}_{50}$ to $70.6 \mathrm{t} \mathrm{ha}^{-1}$ in $\mathrm{I}_{100}$ under DI system, and changed from $46.4 \mathrm{t} \mathrm{ha}^{-1}$ in $\mathrm{PRD}_{50}$ to $71.5 \mathrm{t} \mathrm{ha}^{-1}$ in $\mathrm{I}_{100}$ under SDI system. Both in experimental years, $\mathrm{PRD}_{50}$ produced the lowest yield as 49.8 and $45.9 \mathrm{t} \mathrm{ha}^{-1}$, repectively. Water stress significantly reduced fresh bell pepper yields in both experimental years $(\mathrm{P}<0.05)$. Bell pepper yield was greater in 2016 growing season than that those in 2017. The reason for this difference in yield between years could be attributed to higher temperatures prevailing during flowering stage in 2017. As indicated in Table 4, there was nonsignificant difference in yields between DI and SDI systems in the experimental years. Although there was nonsignificant difference in yield values between the two irrigation systems, all treatments except $\mathrm{I}_{100}$ produced greater yield under SDI than DI. However, irrigation treatments resulted in significantly different yields in 2016 and 2017 growing seasons $(\mathrm{P}<0.01)$. Since there 
Table 4. Statistical analysis results on different variables of bell pepper crop under different irrigation treatments in two experimental years.

\begin{tabular}{|c|c|c|c|c|c|c|c|}
\hline Years & Irrigation treatments & Statistical analysis & Yield & WP & IWP & DM yield & LAI \\
\hline \multirow{10}{*}{2016} & \multirow{4}{*}{ Irrigation systems } & & $\mathrm{t} \mathrm{ha}^{-1}$ & \multicolumn{2}{|c|}{$\longrightarrow \mathrm{kg} \mathrm{m}^{-3}$} & $\mathrm{~kg} \mathrm{ha}^{-1}$ & $m^{2} m^{-2}$ \\
\hline & & $\operatorname{LSD}(0.05)$ & & 0.82 & 0.39 & 175.4 & 0.04 \\
\hline & & Probability & ns & $0.0053 * *$ & $0.0001 * *$ & $0.0079 * *$ & $0.0052 * *$ \\
\hline & & $\mathrm{CV}, \%$ & & 2.4 & 2.6 & 1.9 & 1.5 \\
\hline & \multirow[t]{3}{*}{ Irrigation regimes } & $\operatorname{LSD}(0.05)$ & 5.57 & 0.27 & 0.42 & 135.4 & 0.06 \\
\hline & & Probability & $0.0001 * *$ & $0.0001 * *$ & $0.0001 * *$ & $0.0001 * *$ & $0.0001 * *$ \\
\hline & & $\mathrm{CV}, \%$ & 7.8 & 2.4 & 2.6 & 1.9 & 1.5 \\
\hline & \multirow{3}{*}{$\begin{array}{l}\text { Interaction of irrigation } \\
\text { systems and irrigation } \\
\text { regimes }\end{array}$} & $\operatorname{LSD}(0.05)$ & \multirow{3}{*}{ ns } & 0.38 & 0.59 & 191.4 & 0.08 \\
\hline & & Probability & & $0.0001 * *$ & $0.0001 * *$ & $0.0001 * *$ & $0.0001 * *$ \\
\hline & & $\mathrm{CV}, \%$ & & 2.4 & 2.6 & 1.9 & 1.5 \\
\hline \multirow[t]{9}{*}{2017} & \multirow[t]{3}{*}{ Irrigation systems } & $\operatorname{LSD}(0.05)$ & \multirow{3}{*}{ ns } & 0.55 & 0.76 & 84.5 & 0.05 \\
\hline & & Probability & & $0.0121 *$ & $0.0094 * *$ & $0.0005 * *$ & $0.0321 *$ \\
\hline & & $\mathrm{CV}, \%$ & & 7.0 & 7.2 & 1.9 & 1.6 \\
\hline & \multirow[t]{3}{*}{ Irrigation regimes } & $\operatorname{LSD}(0.05)$ & 4.65 & 0.68 & 0.95 & 106.6 & 0.059 \\
\hline & & Probability & $0.0001 * *$ & $0.0053 * *$ & $0.0001 * *$ & $0.0001 * *$ & $0.0001 * *$ \\
\hline & & $\mathrm{CV}, \%$ & 7.4 & 7.0 & 7.2 & 1.9 & 1.6 \\
\hline & \multirow{3}{*}{$\begin{array}{l}\text { Interaction of irrigation } \\
\text { systems and irrigation } \\
\text { regimes }\end{array}$} & $\operatorname{LSD}(0.05)$ & \multirow{3}{*}{$\mathrm{ns}$} & \multirow{3}{*}{ ns } & \multirow{3}{*}{ ns } & 150.7 & \multirow{3}{*}{ ns } \\
\hline & & Probability & & & & $0.0001 * *$ & \\
\hline & & $\mathrm{CV}, \%$ & & & & 1.9 & \\
\hline
\end{tabular}

*,**Significant differences at 0.05 and 0.01 probability levels, respectively, according to LSD; ns: nonsignificant.

WP: water productivity; IWP: irrigation water productivity; DM: dry matter; LAI: leaf area index.

was nonsignificant difference between the two drip systems regarding the yield values, statistical comparisons of the mean yields were made on yields averaged over the two drip systems (Figure 2a). In both growing seasons, $\mathrm{I}_{100}$, RDI and $\mathrm{I}_{75}$ treatments resulted in similar yields except $\mathrm{I}_{75}$ in 2017 , and significantly greater yields than $\mathrm{I}_{50}$ and $\mathrm{PRD}_{50}$. Treatment $\mathrm{I}_{75}$ produced significantly greater yield than $\mathrm{PRD}_{50}$ and $\mathrm{I}_{50}$. Although $\mathrm{PRD}_{50}$ and $\mathrm{I}_{50}$ treatments received the same amount of irrigation water, $\mathrm{I}_{50}$ resulted in higher yields than $\mathrm{PRD}_{50}$. Treatment $\mathrm{PRD}_{50}$ reduced yields by $30.9 \%$ and $28.5 \%$ in DI and SDI systems, respectively in 2016; and corresponding yield reductions were $36.5 \%$ and $35.1 \%$ in 2017 .

Water stress occurring in $\mathrm{I}_{50}$ and $\mathrm{PRD}_{50}$ significantly reduced bell pepper yield under both drip systems. As mentioned earlier, SWC in these two treatments remained below $50 \%$ available water level during most of the growing seasons. It is assumed that higher fresh weight of $\mathrm{I}_{100}$ fruits is the result of a longer ripening period that allowed higher accumulation of water in these fruits when compared to $\mathrm{I}_{50}$ and $\mathrm{PRD}_{50}$ fruits. The explanation for the reduction in yields in $\mathrm{I}_{50}$ and $\mathrm{PRD}_{50}$ treatments is that the drying of soil decreases the rate of absorption by roots below the transpiration rate by the plant, resulting in reduced leaf area. Many studies confirmed that reductions in water supplied during pepper growth have an advance effect on final yield. For high yield, an adequate water supply is required during the whole crop cycle (Zotarelli et al., 2011; Paul et al., 2013; Adeoye et al., 2014; Kara and Yildirim, 2015). Paul et al. (2013) reported drip irrigated bell pepper yield $28.7 \mathrm{t} \mathrm{ha}^{-1}$ in India. Ferrara et al. (2011) reported that pepper yield decreased gradually from the full irrigation to the treatment stressed during the vegetative phase, and the lowest yield in the treatment stressed during the reproductive growth phase. Santos et al. (2018) determined the total cumulative mean yield for the three harvests was $14.59 \mathrm{t} \mathrm{ha}^{-1}$ for the lysimeter-based system and $13.76 \mathrm{t} \mathrm{ha}^{-1}$ for cultivation using pinus bark. Koksal et al. (2017) reported a maximum average yield of $42.4 \mathrm{t} \mathrm{ha}^{-1}$ for fully irrigated red peppers in the Northern part of Turkey.

Albuquerque et al. (2011), assessing the effects of different levels of irrigation and $\mathrm{K}$ doses in soil-grown bell pepper culture, found a mean yield of $18.58 \mathrm{t} \mathrm{ha}^{-1}$ over five harvests. Nagaz et al. (2012) reported similar findings with this study, they found highest yields under full irrigation (22.3 and $\left.24.4 \mathrm{t} \mathrm{ha}^{-1}\right)$ although there was nonsignificant difference with the RDI treatment (full irrigation during vegetative growth stage, deficit irrigation during ripining stage $\mathrm{I}_{100}-\mathrm{I}_{60}$ ). However, $\mathrm{I}_{80}$ and $\mathrm{I}_{60}$ treatments caused significant reductions in bell pepper yields through a reduction in fruits number $\mathrm{m}^{-2}$ and average fruit weight in comparison with $\mathrm{I}_{100}$ treatment. The RDI method can save a substantial amount of water and maintain 
Figure 2. Mean values averaged of different bell pepper parameters over two drip irrigation systems (DI and SDI) for different treatments; full irrigation $\left(\mathrm{I}_{100}\right)$, regulated deficit irrigation (RDI), partial rootzone drying $\left(\mathrm{PRD}_{50}\right)$, deficit irrigations $\left(I_{75}\right.$ and $\left.I_{50}\right)$ in two experimental years.
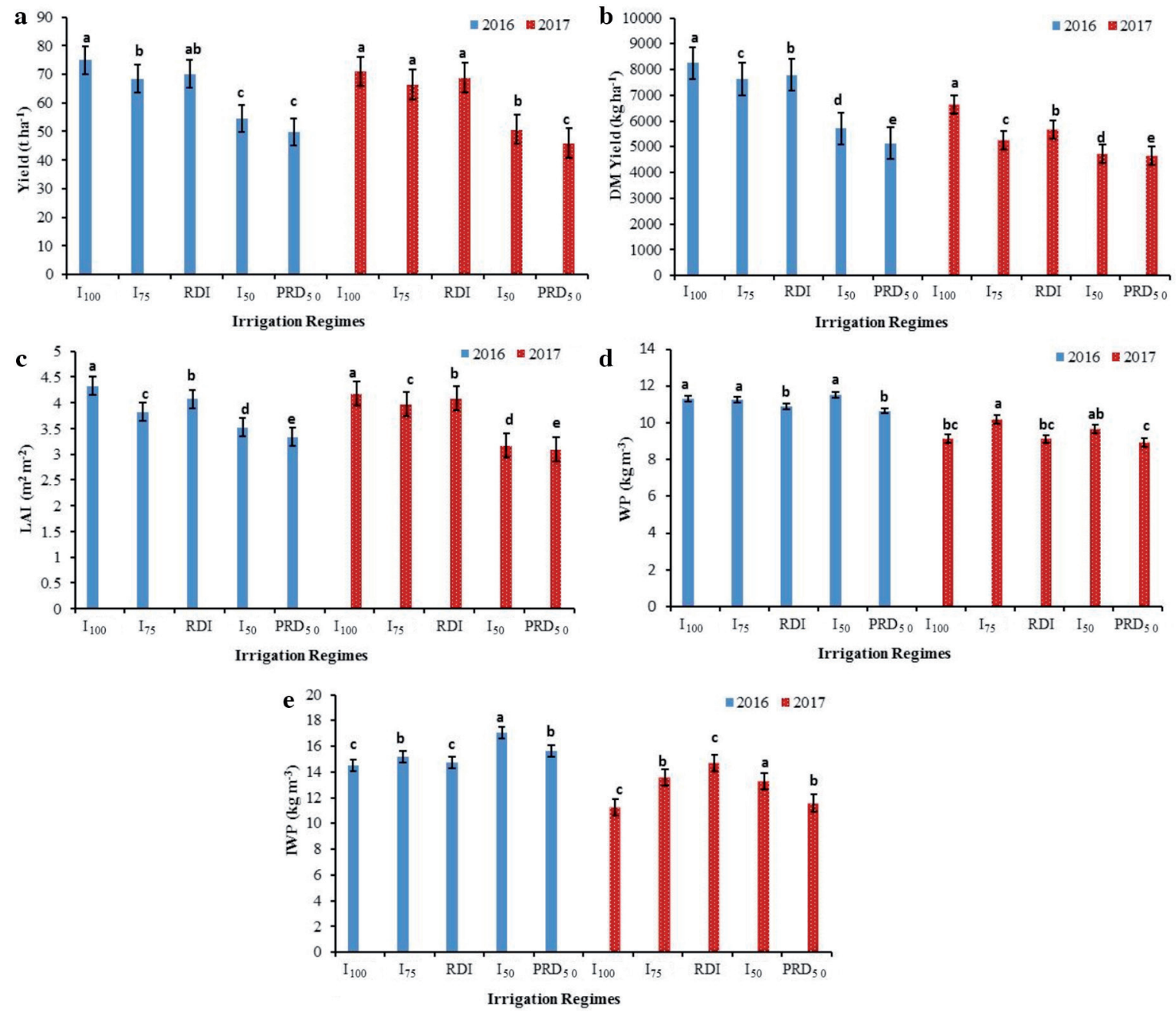

Vertical bars represent standard error among four independent replicates. Different lowercase letters indicate significant differences.

(a) Yield; (b) DM yield; (c) LAI; (d) WP; (e) IWP.

DM: Dry matter; LAI: leaf area index; WP: water productivity; IWP: irrigation water productivity; $\mathrm{I}_{100}$ : full irrigation; $\mathrm{I}_{75}$ : deficit irrigation $\left(75 \% \mathrm{I}_{100}\right) ; \mathrm{I}_{50}$ : deficit irrigation $\left(50 \% \mathrm{I}_{100}\right)$.

yield in bell pepper production. The findings of the present study confirm these findings by Nagaz et al. (2012). Dimple et al. (2019) reported that drip irrigation applied with $80 \%$ ETa was the optimum irrigation amount. The maximum yields of $42.64 \mathrm{t} \mathrm{ha}^{-1}$ were obtained under this treatment. Thus, RDI and $\mathrm{I}_{75}$ irrigation treatments can save substantial irrigation water while producing similar yields with full irrigation under the Mediterranean climatic conditions.

\section{Dry matter yield}

Above ground DM yields from the treatments varied from $5610 \mathrm{~kg} \mathrm{ha}^{-1}$ in $\mathrm{I}_{50}$ to $8480 \mathrm{~kg} \mathrm{ha}^{-1}$ in $\mathrm{I}_{100}$ under DI, and it changed between $4670 \mathrm{~kg} \mathrm{ha}^{-1}$ in $\mathrm{I}_{50}$ and $8040 \mathrm{~kg} \mathrm{ha}^{-1}$ in $\mathrm{I}_{100}$ under SDI in 2016. In 2017, DM yield values varied from $4320 \mathrm{~kg} \mathrm{ha}^{-1}$ in $\mathrm{PRD}_{50}$ to $6110 \mathrm{~kg} \mathrm{ha}^{-1}$ in $\mathrm{I}_{100}$ under DI, and changed between $4610 \mathrm{~kg} \mathrm{ha}^{-1}$ in $\mathrm{PRD}_{50}$ and $7140 \mathrm{~kg} \mathrm{ha}^{-1}$ in $\mathrm{I}_{100}$ under SDI (Table 3). Irrigation methods, treatments and their interaction were significantly different with regards to DM yields in both seasons $(\mathrm{P}<0.01)$ (Table 4) and comparison of DM yield values averaged over two drip systems for the different treatments in the experimental years (Figure 2b). Surface drip produced significantly higher DM yields than SDI in the first 
year, but in the second year SDI resulted in greater DM yields than DI plots. In the 2016 development period, the lowest DM yields were obtained for SDI-I $\mathrm{I}_{50}$, while the highest DM yields were obtained for DI-I $\mathrm{I}_{100}$. In the 2017 growing season, the lowest DM yield was obtained for DI-PRD ${ }_{50}$, while the highest was obtained for SDI- $\mathrm{I}_{100}$. The DM yields of the study in 2016 were significantly higher than those in 2017. Treatment RDI produced DM yields lower than $\mathrm{I}_{100}$, but significantly greater than the other treatments. Water stress occurring in deficit irrigation treatments of $\mathrm{I}_{50}$ and $\mathrm{PRD}_{50}$ reduced DM yield significantly in comparison with $\mathrm{I}_{100}$, RDI and $\mathrm{I}_{75}$ treatments under both drip systems. It was observed that DI treatments produced significantly greater biomass yields than SDI treatments in 2016 but conversely in the second year. Full irrigation treatments produced significantly greater DM yield than other treatments studied, RDI produced DM yields just next to the $\mathrm{I}_{100}$, and DM yield decreased with increasing water stress level in $\mathrm{I}_{50}$ and $\mathrm{PRD}_{50}$. Decreasing the water supply caused a significant decrease in the total DM yields. Generally, plants exposed to water stress have lower evapotranspiration which further leads to the development of certain water stress symptoms such as reduced leaf area, decreased plant growth (Wang et al., 2015) and changes in physiological and biochemical processes such as stomatal conductance, leaf water status, photosynthesis, sap flow, leaf temperature, hormonal balance, osmotic adjustments (Parkash and Singh, 2020). Thus, reduced DM yields under deficit irrigation treatments $\left(\mathrm{I}_{50}\right.$ and $\left.\mathrm{PRD}_{50}\right)$ were because of water stress occurring throughout the growing season in these treatments. In the present study, by considering the fact that the total dry mass of bell pepper plant was markedly affected by $\mathrm{I}_{50}$, and $\mathrm{PRD}_{50}$ led to decreased water productivity (WP) and bell pepper yield. Karam and Nangia (2016) reported significant differences in DM production between full and deficit irrigation treatments. These differences became more evident at mature fruit stage (87 DAT), where full irrigated plants produced $508 \mathrm{~g} \mathrm{~m}^{-2}$, while deficit-irrigated treatments produced DM yields varying between 260 and $460 \mathrm{~g} \mathrm{~m}^{-2}$. Dry matter production was reduced after mature fruit stage in all treatments probably because of leaf senescence.

\section{Leaf area index}

Maximum leaf area index (LAI) values for different treatments under DI and SDI systems for both experimental years are presented in Table 3. In 2016, maximum LAI values from the irrigated treatments varied from 3.29 in $\mathrm{I}_{50}$ to 4.28 in $\mathrm{I}_{100}$ under DI, and it changed between 3.35 in $\mathrm{I}_{50}$ and 4.35 in $\mathrm{I}_{100}$ under SDI. In 2017, maximum LAI varied from 3.06 in $\mathrm{PRD}_{50}$ to 4.15 in $\mathrm{I}_{100}$ under DI, and changed between 3.14 in $\mathrm{PRD}_{50}$ and 4.19 in $\mathrm{I}_{100}$ under SDI (Table 3). In 2016, irrigation method and irrigation treatment interaction were significantly different with regards to maximum LAI in first season $(\mathrm{P}<0.01)$ (Table 4) and comparison to LAI averaged over two drip systems for the different treatments in the experimental years (Figure 2c). In 2017, irrigation method $(\mathrm{P}<0.05)$ and irrigation treatment $(\mathrm{P}<0.01)$ were significantly different with regards to mean LAI. The $\mathrm{I}_{100}$ treatments under both systems resulted in highest LAI followed by RDI and $\mathrm{I}_{75}$ treatments. In both years of the study, higher LAI were obtained in SDI method compared to DI method. In all treatments LAI values decreased towards the end of season due to leaf senecensence; RDI had greater LAI than the other deficit irrigation treatments but lower than $\mathrm{I}_{100}$ treatment plots under both drip systems. Water stress occurring in $\mathrm{PRD}_{50}$ and $\mathrm{I}_{50}$ resulted in lower LAI than those in other treatments.

Highest LAI were observed in $\mathrm{I}_{100}$ treatments under both systems followed by RDI and $\mathrm{I}_{75}$ treatments. In both years of the study, higher LAI were obtained in SDI method compared to DI method. In all treatments LAI decreased towards the end of season due to leaf senecensence; RDI had greater LAI than the other deficit irrigation treatments but lower than $\mathrm{I}_{100}$ treatment plots under both drip systems. Water stress occurring in $\mathrm{PRD}_{50}$ and $\mathrm{I}_{50}$ resulted in lower LAI than those in other treatments. Adeoye et al. (2014) found highest leaf area values of bell pepper plants in plot with $6 \mathrm{~d}$ irrigation interval and recorded minimum leaf area in the control plot in North central Nigeria. Demir et al. (2018) observed the highest $\left(4.59 \mathrm{~m}^{2} \mathrm{~m}^{-2}\right)$ and least $\left(1.26 \mathrm{~m}^{2} \mathrm{~m}^{-2}\right)$ LAI for sweet pepper in SDI- $\mathrm{I}_{75} \mathrm{~N}_{210}$ and DI- $\mathrm{I}_{50} \mathrm{~N}_{0}$, respectively, in Ankara, Turkey. On bell pepper, water stress during the vegetative and fruting stage decreases LAI, DM, and yield. Similar results were obtained by Ismail (2012) in bird pepper, reporting a consequently yield decrease under water stress conditons.

\section{Leaf water potential}

The fluctuations in leaf water potential (LWP) values prior to irrigations for different irrigation treatments with time during the 2016 and 2017 growing seasons are shown in Figures 3a-3d. In general, LWP decreased with increasing water stress. In DI treatment plots, LWP ranged between -0.71 MPa in $\mathrm{I}_{100}$ and $-2.40 \mathrm{MPa}$ in $\mathrm{PRD}_{50}$ and varied between -0.73 $\mathrm{MPa}$ in $\mathrm{I}_{100}$ and $-2.35 \mathrm{MPa}$ in $\mathrm{PRD}_{50}$ under SDI in 2016. In the second year, LWP varied from $-0.85 \mathrm{MPa}$ in $\mathrm{I}_{100}$ to -2.37 
Figure 3. Leaf water potential (LWP) variation in bell pepper for different treatments under surface (DI) and subsurface drip irrigation (SDI) systems; full irrigation $\left(\mathrm{I}_{100}\right)$, regulated deficit irrigation $(\mathrm{RDI})$, partial rootzone drying $\left(\mathrm{PRD}_{50}\right)$, deficit irrigations $\left(\mathbf{I}_{75}\right.$ and $\left.\mathbf{I}_{50}\right)$.
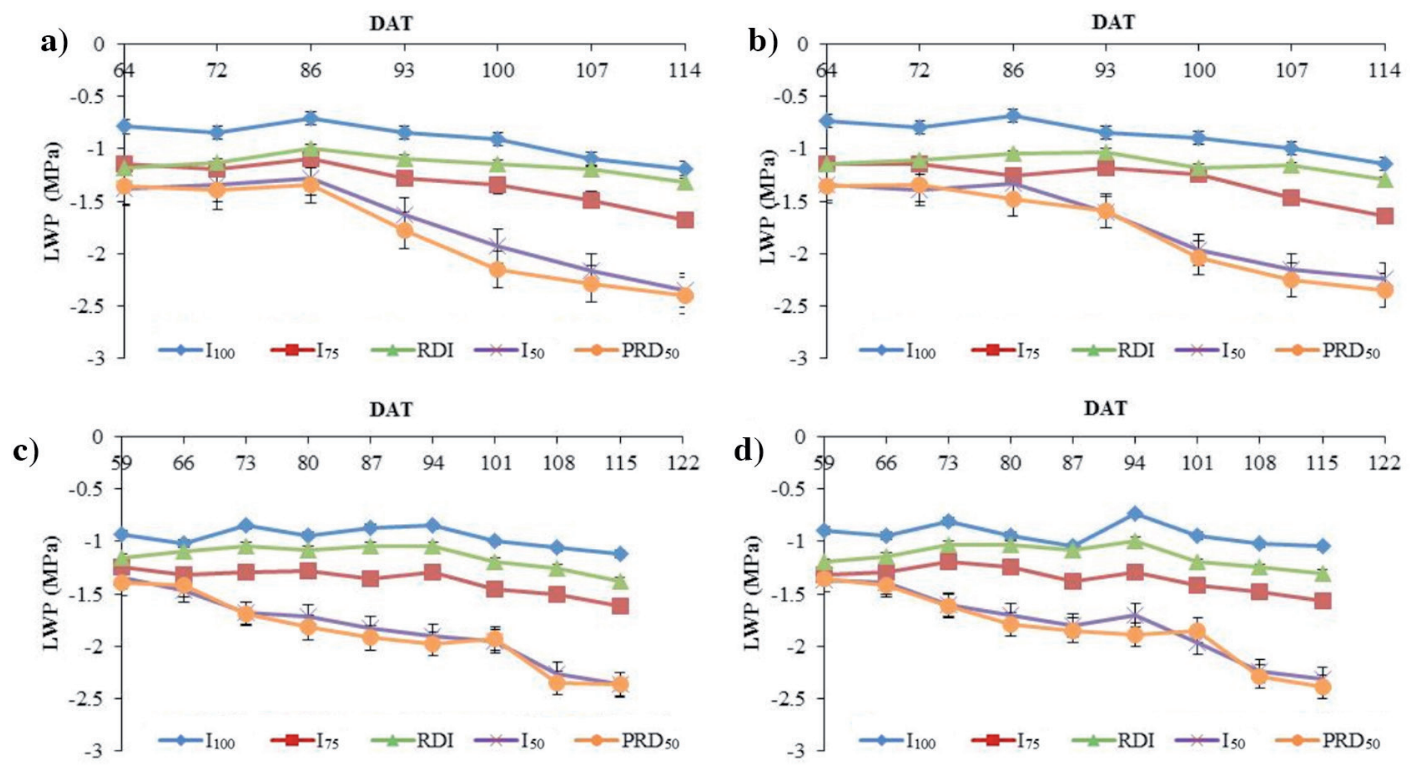

Vertical bars represent standard errors.

(a) LWP in DI in 2016; (b) LWP in SDI in 2016; (c) LWP in DI in 2017; (d) LWP in SDI in 2017.

$\mathrm{I}_{100}$ : Full irrigation; $\mathrm{I}_{75}$ : deficit irrigation $\left(75 \% \mathrm{I}_{100}\right) ; \mathrm{I}_{50}$ : deficit irrigation $\left(50 \% \mathrm{I}_{100}\right)$; DAT: days after transplanting.

$\mathrm{MPa}$ in $\mathrm{PRD}_{50}$ under DI system and changed from -0.74 MPa in $\mathrm{I}_{100}$ and -2.39 MPa in $\mathrm{PRD}_{50}$ under SDI. Seasonal average LWP ranged between -0.91 MPa in $\mathrm{I}_{100}$ and $-1.82 \mathrm{MPa}$ in $\mathrm{PRD}_{50}$ in $\mathrm{DI}$; varied from -0.87 MPa in $\mathrm{I}_{100}$ to $-1.77 \mathrm{MPa}$ in $\mathrm{PRD}_{50}$ in SDI in 2016. In the second year, the corresponding values were $-0.96 \mathrm{MPa}$ in $\mathrm{I}_{100}$ and $-1.88 \mathrm{MPa}$ in $\mathrm{PRD}_{50}$ in DI, and -0.94 MPa in $\mathrm{I}_{100} \mathrm{MPa}$ and -1.83 in $\mathrm{PRD}_{50}$ in SDI. Slightly lower LWP values were observed in SDI plots as compared to DI plots in the experimental years. Greater the soil water stress level observed in $\mathrm{I}_{50}$ and $\mathrm{PRD}_{50}$, the lower the LWP. The LWP measured during the vegetative and flowering growth stages were higher than those observed during the reproductive growth stage. In other words, LWP decreased with time during the growth period of bell pepper.

Greater LWP were observed in $\mathrm{I}_{100}$ treatment plots than the deficit irrigation treatment plots under both drip systems. Water stress occurring in $\mathrm{I}_{50}$ and $\mathrm{PRD}_{50}$ treatments resulted in reduced LAI due lower water consumption. We observed slightly higher LWP in SDI than in the DI plots; however, the difference between the two irrigation systems was nonsignificant. In 2017, again slightly higher LWP were observed as compared to the 2016. The difference can be attributed to varying weather conditions between the two exprimental years. The lowest LWP were observed in $\mathrm{I}_{50}$ and $\mathrm{PRD}_{50}$ plots. Generally, LWP decreased towards the end of season in comparison to the beginning of the season due to leaf senescence. During the growing cycle, bell pepper plants under water stress conditions (photosynthesis, LWP, LAI, and the amount of photosynthetically active radiation [PAR] intercepted by the canopy) have all been shown to decline (Sezen et al., 2019). The LWP changed with time according to the SWC in stressed treatments, $\mathrm{I}_{50}$ and PRD $\mathrm{D}_{50}$, in which lowest LWP were observed. Water stress during vegetative and reproductive stages reduced considerably LWP of bell pepper. Ismail (2012) observed LWP decreased markedly in deficit irrigation treatments because fruit are stronger sinks for water than for vegetative parts of plants. Therefore, competition for water from developing reproductive sinks coupled with increased evaporative demand due to rising temperature during the late growing season may have caused the reduction in LWP in Ishigaki, Japan. Sezen et al. (2019) reported that red pepper performed best at full irrigation with a corresponding LWP of -0.65 to $-0.53 \mathrm{MPa}$ for experimental years in the Mediterranean region. In the present study, averaged over $2 \mathrm{yr}$ and systems, LWP in $\mathrm{I}_{100}$, RDI and $\mathrm{I}_{75}$ treatments were $-0.92,-1.14$, and $-1.34 \mathrm{MPa}$, respectively. Considering the increasing water scarcity conditions in the Mediterranean region, RDI and $\mathrm{I}_{75}$ appear to be good alternative to full irrigation for high yields and also high-water productivity. 


\section{Relationships between LWP, yield, DM yield, LAI and mean SWC}

The significant curvilinear relationships between LWP (as the independent variable) and yield, DM yield, maximum LAI, and SWC (as the dependent variables) were determined in the experimental years and these relationships were presented in Figures $4 a-4 b$ and $5 a-5 b$, respectively. For the growing seasons, the relationship between LWP and yield had high determination coefficients that yielded $\mathrm{R}^{2}=0.99$ for DI and 0.99 for SDI in first and second year, respective values were $\mathrm{R}^{2}=0.99$ and 0.96 . The relationship between $\mathrm{LWP}$ and $\mathrm{DM}$ yield with high determination coefficients yielded $\mathrm{R}^{2}=0.98$ for DI and 0.89 for SDI in first and second year, $\mathrm{R}^{2}=0.99$ and 0.96 respectively. The relationship between LWP and maximum LAI with high determination coefficients yielded $\mathrm{R}^{2}=0.87$ for DI and 0.98 for SDI in first and second year, $\mathrm{R}^{2}=0.99$ and 0.99 respectively. The relationship between LWP and SWC high determination coefficients that yielded $\mathrm{R}^{2}=0.98$ for DI and 0.98 for SDI in first and second year, $\mathrm{R}^{2}=0.99$ and 0.98 respectively.

In general, LWP correlated significantly $(\mathrm{P}<0.01)$ and positively with yield, DM yield, LAI, and mean SWC indicating that all four parameters declined with decreasing LWP values. All these relations are best described by significant second order polynomial equations with high $\mathrm{R}^{2}$ values. Pepper yield, DM yield, LAI and SWC decreased with decreasing LWP. Demir et al. (2018) found linear relationships between yield and LWP for sweet pepper in Ankara; Sezen et al. (2019) determined significant linear relationships between mean LWP values and red pepper yield in the Mediterranean region of Turkey. In the present study a second order polynomial equations were found to describe best the relationship between LWP and yield, DM, LAI, and SWC.

Figure 4. Relationships between leaf water potential (LWP) and yield and dry matter yield (DMY) (a), maximum leaf area index (LAI) and mean soil water content (SWC) (b) for bell pepper in the 2016 growing season.
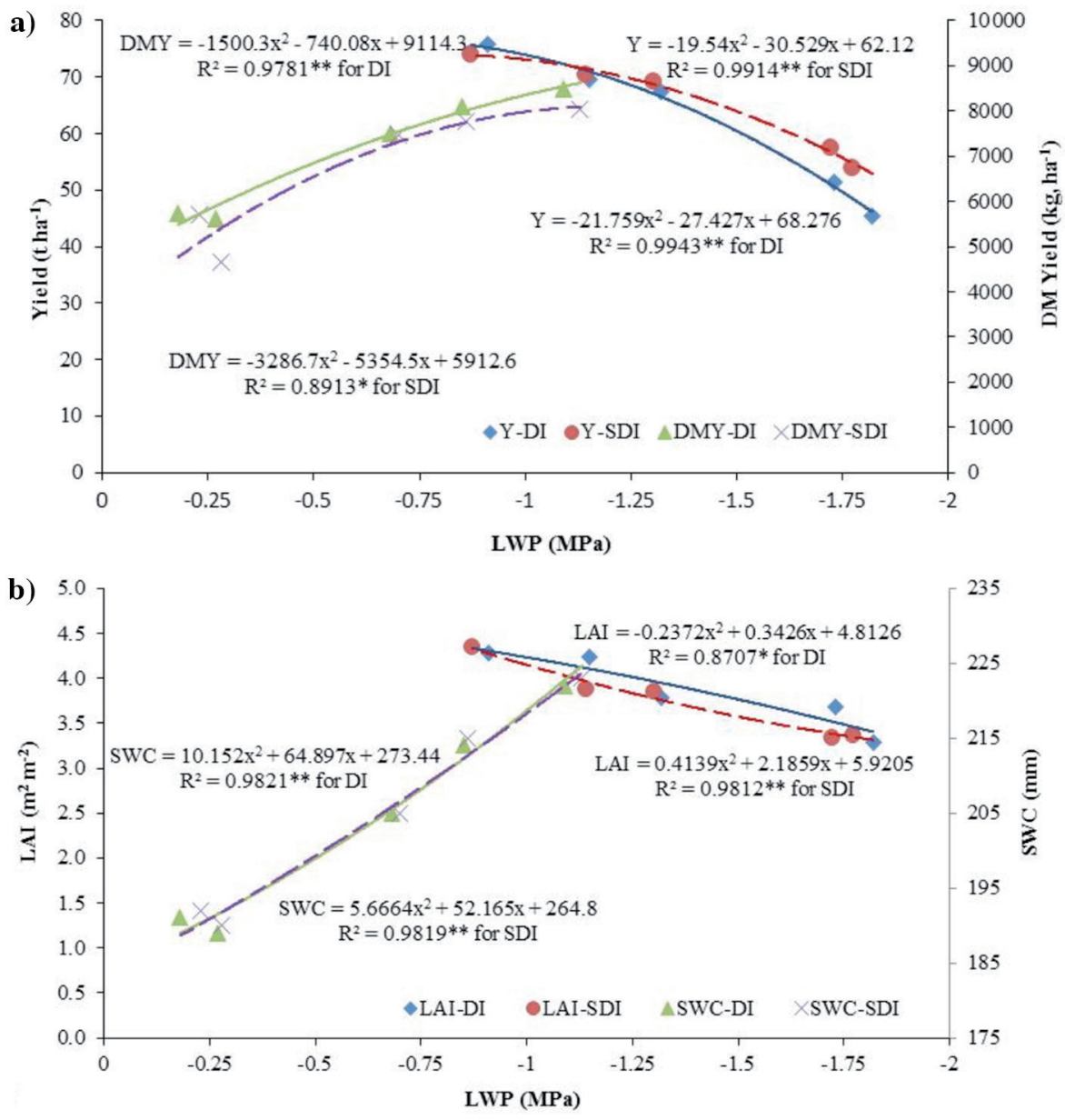

*, **Significant differences at 0.05 and 0.01 probability levels, respectively, according to LSD. DI: Surface drip irrigation; SDI: subsurface drip irrigation. 
Figure 5. Relationships between leaf water potential (LWP) and yield and dry matter yield (DMY) (a), maximum leaf area index (LAI) and mean soil water content (SWC) (b) for bell pepper in the 2017 growing season.
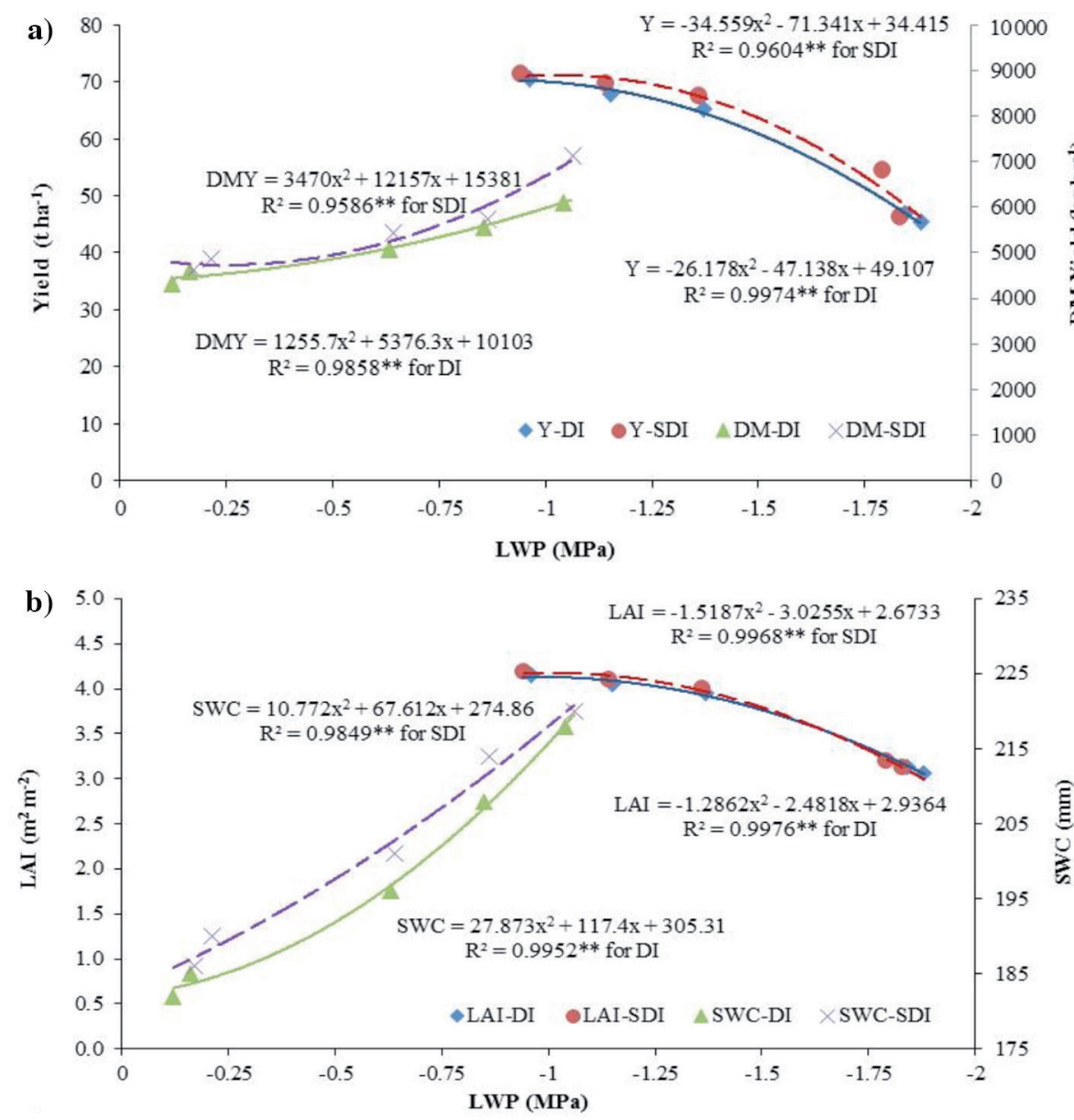

$*, * *$ Significant differences at 0.05 and 0.01 probability levels, respectively, according to LSD. DI: Surface drip irrigation; SDI: subsurface drip irrigation.

\section{Water productivity and irrigation water productivity}

Water productivity (WP) and irrigation water productivity (IWP) for the different irrigation treatments for two drip irrigation methods in both experimental years (2016 and 2017) are given in Table 3. The statistical analysis of the parameters considered in this study (Table 4, Figures $2 \mathrm{~d}$ and 2e) show comparison of WP and IWP averaged over two drip systems for the different treatments in the experimental years. Irrigation systems, irrigation regimes and their interactions were found to be significantly different in the experimental years $(\mathrm{P}<0.01)$. In 2016, WP ranged between $9.4 \mathrm{~kg} \mathrm{~m}^{-3}$ in DI-PRD ${ }_{50}$ and $12.7 \mathrm{~kg} \mathrm{~m}^{-3}$ in SDI-I $\mathrm{I}_{75}$ and SDI-I $\mathrm{I}_{50}$. In 2017, WP ranged between $8.6 \mathrm{~kg} \mathrm{~m}^{-3}$ in RDI and $9.7 \mathrm{~kg} \mathrm{~m}^{-3}$ in $\mathrm{I}_{75}$ under DI, and varied from 9.4 in $\mathrm{I}_{100}$ and $\mathrm{I}_{50}$ and $10.7 \mathrm{~kg} \mathrm{~m}^{-3}$ in $\mathrm{I}_{75}$ under SDI. It was observed that greater the irrigation water applied the lower is the WP. However, $\mathrm{I}_{75}$ treatment proved to be a good strategy for improving WP under both drip systems.

Irrigation water productivity (IWP) values ranged between $9.4 \mathrm{~kg} \mathrm{~m}^{-3}$ in DI- $\mathrm{I}_{75}$ and $18.8 \mathrm{~kg} \mathrm{~m}^{-3}$ in SDI-PRD 50 . Irrigation method and irrigation treatment interaction was significantly different with regards to IWP in first season $(\mathrm{P}<0.01)$ (Tables 3 and 4). In 2017, IWP ranged between $10.9 \mathrm{~kg} \mathrm{~m}^{-3}$ in $\mathrm{I}_{100}$ and $13.1 \mathrm{~kg} \mathrm{~m}^{-3}$ in $\mathrm{PRD}_{50}$ under DI, and varied from 11.6 in $\mathrm{I}_{100}$ and $\mathrm{I}_{50}$ and $10.7 \mathrm{~kg} \mathrm{~m}^{-3}$ in $\mathrm{PRD}_{50}$ under SDI. Irrigation method $(\mathrm{P}<0.01)$ and irrigation treatment $(\mathrm{P}<0.01)$ was significantly different with regards to WP. 
The WP and IWP of this study were similar to those previously reported by Kong et al. (2012) determined WP between 7.76 and $10.71 \mathrm{~kg} \mathrm{~m}^{-3}$ in drip irrigated bell pepper; Sezen et al. (2014) reported WP of $6.9 \mathrm{~kg} \mathrm{~m}^{-3}$ and IWP of $5.7 \mathrm{~kg} \mathrm{~m}^{-3}$ in red pepper; Shao et al. (2010) determined WP and IWP for hot pepper varying between 6.7 to $10.4 \mathrm{~kg} \mathrm{~m}^{-3}$ and 6.3 to 10.6 $\mathrm{kg} \mathrm{m}^{-3}$, respectively; Demirel et al. (2012) determined WP and IWP for pepper varying from 2.4 to $7.0 \mathrm{~kg} \mathrm{~m}^{-3}$ and 0.3 to $9.1 \mathrm{~kg} \mathrm{~m}^{-3}$, respectively. For fresh pepper yield, Karam and Nangia (2016) found that WP varied from $5.92 \mathrm{~kg} \mathrm{~m}^{-3} \mathrm{on}$ the control to values varying between 7.16 and $7.78 \mathrm{~kg} \mathrm{~m}^{-3}$ on deficit-irrigated treatments. Kara and Yildirim (2015) reported for pepper with irrigation levels of $0.2 \%, 0.5 \%, 0.8 \%, 1.0 \%$ and $1.2 \% \mathrm{ETa}$, WP between 6.0, 4.1, 3.6, 2.7, and $2.1 \mathrm{~kg} \mathrm{~m}^{-3}$, respectively. Rodríguez Padrón et al. (2014) reported that the daily watering frequency demonstrated a WP of 18.73 $\mathrm{kg} \mathrm{m}^{-3}$ with a production of $4.71 \mathrm{~kg} \mathrm{~m}^{-2}(60 \% \mathrm{ETa})$. However, watering with a frequency each $2 \mathrm{~d}$ reached $4.46 \mathrm{~kg} \mathrm{~m}^{-2}$ and efficiency of $12.93 \mathrm{~kg} \mathrm{~m}^{-3}$ (80\% ETa). Nagaz et al. (2012) reported that WP varied between 2.31 and $5.49 \mathrm{~kg} \mathrm{~m}^{-3}$. The WP was found to vary significantly among treatments, where the highest and the lowest values were observed for $\mathrm{I}_{60}$ treatment and farmer practice, respectively. In general, IWP increases with increasing water stress level.

\section{CONCLUSIONS}

The results revealed that regulated deficit irrigation (RDI) produced yields same as full irrigation $\left(\mathrm{I}_{100}\right)$ treatment in both experimental years. Treatment RDI saved 5\% and 12\% water as compared with $\mathrm{I}_{100}$ under surface drip (DI) and $10 \%$ and $6 \%$ under subsurface drip irrigation (SDI) systems, respectively, in the experimental years. Treatment $\mathrm{I}_{75}$ resulted in an average water saving of $20.6 \%$ and $26.7 \%$ for DI and SDI, respectively. Average yield reductions of $6.8 \%$ and $9.9 \%$ were observed in for $\mathrm{I}_{75}$ under SDI, and DI respectively as compared to $\mathrm{I}_{100}$. Thus, both RDI and $\mathrm{I}_{75}$ treatments appear to be good alternatives to $I_{100}$ in the Mediterranean environmental conditions. The results show that the water status of the bell pepper plant determined by the leaf water potential (LWP) was significantly affected by irrigation treatments. It was observed slightly higher LWP in SDI plots than in the DI plots, however the difference between the two irrigation systems was nonsignificant. The results revealed that bell pepper should be irrigated at LWP around -0.89 and $-0.95 \mathrm{MPa}$ for high yields in the Mediterranean region. In general, the LWP correlated significantly $(\mathrm{P}<0.01)$ and negatively with bell pepper yield, DM yield, maximum leaf area index, and mean soil water content. In conclusion, RDI resulted in higher yields, in which applying irrigation water by reducing the crop water requirement by $50 \%$ at the vegetative growth stage has a significant contribution for sustainable and efficient irrigation water utilization at water deficient areas without any loss on fresh bell pepper yield and DM yield; it is recommended along with conventional deficit irrigation $\left(\mathrm{I}_{75}\right)$ in the semi-arid Mediterranean area. Midday LWP have been proven to be good indicator of water status of plants, they can be utilized in irrigation decision making together with soil water monitoring and/or evapotranspiration models.

\section{ACKNOWLEDGEMENTS}

The authors would like to thank the Turkish Scientific and Technical Research Council (TUBITAK) for its financial support for the project TUBITAK ERA-NET-215O951. I would like to thank Prof. Dr. Attila Yazar, retired academic staff, Çukurova University in Adana, Turkey for valuable comments on the manuscript.

\section{REFERENCES}

Abdelkhalik, A., Pascual, B., Nájera, I., Domene, M.A., Baixauli, C., and Pascual Seva, N. 2020. Effects of deficit irrigation on the yield and irrigation water use efficiency of drip irrigated sweet pepper (Capsicum annuum L.) under Mediterranean conditions. Irrigation Science 38:89-104.

Adeoye, P.A., Adesiji, R.A., Oloruntade, A.J., and Njemanze, C.F. 2014. Effect of irrigation intervals on growth and yield of bell pepper (Capsicum annuum) in a tropical semi-arid region. American Journal of Experimental Agriculture 4(5):515-524.

Albuquerque, F.S., Silva, E.F.F., Albuquerque Filho, J.A.C., e Nunes, M.F.F.N. 2011. Crescimento e rendimento de pimentão fertirrigado sob diferentes lâminas de irrigação e doses de potássio. Revista Brasileira de Engenharia Agrícola e Ambiental 15:686-694.

Bozkurt Colak, Y., Yazar, A., Gönen, E., and Eroglu, E.C. 2018. Yield and quality response of surface and subsurface drip irrigated eggplant and comparison of net returns. Agricultural Water Management 206:165-175. 
Bozkurt Colak, Y., Yazar, A., Sesveren, S., and Colak, I. 2017. Evaluation of yield and leaf water potential (LWP) for eggplant under varying irrigation regimes using surface and subsurface drip systems. Scientia Horticulturae 219:10-21.

Chai, Q., Gan, Y., Zhao, C., Xu, H.L., Waskom, R.M., Niu, Y., et al. 2016. Regulated deficit irrigation for crop production under drought stress. A review. Agronomy for Sustainable Development 36:3.

Chartzoulakis, K., and Maria, B. 2015. Sustainable water management in agriculture under climate change. Agriculture and Agricultural Science Procedia 4:88-95.

Demir, Z., Özbahce, A., and Demir, Y. 2018. Determination of effects of fertigation applications with surface and subsurface drip irrigation systems on the yield and quality of pepper under the deficit of water TAGEM Project final report. Project $\mathrm{Nr}$ TAGEM/TSKAD/15/A13/P02/1.p. 127.

Demirel, K., Genc, L., and Sacan, M. 2012. Effects of different irrigation levels on pepper yield and quality parameters in semiarid conditions. Journal of Tekirdag Agricultural Faculty 9(2):7-15.

Dimple, Bhakar, S.R., Lakhawat, S.S., Jitendra, R., Mittal, H.K., and Kothari, M. 2019. Response of deficit drip irrigation on production and growth parameters of capsicum (Capsicum annuиm) inside naturally ventilated polyhouse. IOP Conference Series: Earth and Environmental Science 301:012005.

Evett, S.R., Stone, K.C., Schwartz, R.C., O’Shaughnessy, S.A., Colaizzi, P.D., Anderson, S.K., et al. 2019. Resolving discrepancies between laboratory-determined field capacity values and field water content observations: Implications for irrigation management. Irrigation Science 37(6):751-759.

Ferrara, A., Lovelli, S., Di Tommaso, T., and Perniola, M. 2011. Flowering, growth and fruit setting in greenhouse bell pepper under water stress. Journal of Agronomy 10:12-19.

Galindo, A., Collado-González, J., Griñán, I., Corell, M., Centeno, A., Martín- Palomo, M.J., et al. 2018. Deficit irrigation and emerging fruit crops as a strategy to save water in Mediterranean semiarid agrosystems. Agricultural Water Management 202:311-324.

Hashem, M.S., Zin El-Abedin, T., and Al-Ghobari H.M. 2019. Rational water use by applying regulated deficit and partial root-zone drying irrigation techniques in tomato under arid conditions. Chilean Journal of Agricultural Research 79:75-88.

Ismail, S.M. 2012. Water use efficiency and bird pepper production as affected by deficit irrigation practice. International Journal of Agriculture and Forestry 2(5):262-267.

Kara, O.H., and Yildirim, M. 2015. Water and radiation use efficiencies of pepper (Capsicum annuum L. cv. Carliston). Scholars Journal of Agriculture and Veterinary Sciences 2(2A):87-93.

Karam, F., and Nangia, V. 2016. Improving water productivity in semi-arid environments through regulated deficit irrigation. Annals of Arid Zone 55(3-4):79-87.

Koksal, E.S., Tasan, M., Artik, C., and Gowda, P. 2017. Evaluation of financial efficiency of drip-irrigation of red pepper based on evapotranspiration calculated using an iterative soil water-budget approach. Scientia Horticulturae 226:398-405.

Kong, Q., Li, G., Wang, Y., and Huo, H. 2012. Bell pepper response to surface and subsurface drip irrigation under different fertigation levels. Irrigation Science 30(3):233-245.

Lamm, F.R., and Rogers, D.H. 2017. Longevity and performance of a subsurface drip irrigation system. Transactions of the ASABE 60:931-939.

MGM. 2019. Climate data. General Directorate of Meteorology (MGM) of Turkey, Ankara, Turkey.

Mohawesh, O. 2018. Utilizing deficit irrigation to enhance growth performance and water-use effciency of eggplant in arid environments. Journal of Agricultural Science and Technology 18:265-276.

Nagaz, K., Masmoudi, M.M., and Mechlia, N.B. 2012. Effects of deficit drip-irrigation scheduling regimes with saline water on pepper yield, water productivity and soil salinity under arid conditions of Tunisia. Journal of Agriculture and Environment for International Development 106(2):85-103.

Parkash, V., and Singh, S. 2020. A review on potential plant-based water stress indicators for vegetable crops. Sustainability 12(10):3945. doi:10.3390/su12103945.

Paul, J.C., Mishra, J.N., Pradhan, P.L., and Panigrahi, B. 2013. Effect of drip and surface irrigation on yield, water use efficiency and economics of capsicum (Capsicum annuum L.) grown under mulch and non mulch conditions in eastern coastal India. European Journal of Sustainable Development 2(1):99-108.

Rienth, M., and Scholasch, T. 2019. State of the art of tools and methods to assess vine water status. OENO One 53(4):2403.

Rodríguez Padrón, R.A., Ramírez, L.R., Swarowsky, A., y Daboín, J.R. 2014. Efecto del riego deficitario y diferentes frecuencias en la producción del cultivo de pimentón. Interciencia 39(8):591-596.

Santos, I.M.S., Santos Júnior, P.P.S., da Silva, R.R., de Oliveira, G.M., and de Queiroz, S.O.P. 2018. Irrigation management methods for the production of bell pepper in agricultural substrates. Bragantia 77(3):510-518.

Sezen, S.M., Yazar, A., Dasgan, Y., Yucel, S., Akyildiz, A., Tekin, S., et al. 2014. Evaluation of crop water stress index (CWSI) for red pepper with drip and furrow irrigation under varying irrigation regimes. Agricultural Water Management 143:59-70.

Sezen, S.M., Yazar, A., and Tekin, S. 2019. Physiological response of red pepper to different irrigation regimes under drip irrigation in the mediterranean region of Turkey. Scientia Horticulturae 245:280-288. 
Shackel, K.A., Buchner, R.P., Connell, J.H., Edstrom, J.P., Fulton, A.E., Holtz, B.A., et al. 2010. Midday stem water potential as a basis for irrigation scheduling. $5^{\text {th }}$ National Decennial Irrigation Conference Proceedings, Phoenix. 5-8 December. American Society of Agricultural and Biological Engineers, St. Joseph, Michigan, USA.

Shammout, M.W., Qtaishat, T., Rawabdeh, H., and Shatanawi, M. 2018. Improving water use efficiency under deficit 1 rrigation in the Jordan Valley. Sustainability 10(4317):1-12.

Shao, G.C., Liu, N., Zhang, Z.Y., Yu, S.E., and Chen, C.R. 2010. Growth, yield and water use efficiency response of greenhousegrown hot pepper under time-space deficit irrigation. Scientia Horticulturae 126(2):172-179.

Wang, X., Zhao, C., Guo, N., Li, Y., Jian, S., and Yu, K. 2015. Determining the canopy water stress for spring wheat using canopy hyperspectral reflectance data in loess plateau semiarid regions. Spectroscopy Letters 48:492-498.

Yahaya, O., Alao, F., and Odigie, C.J. 2012. Yield, crop-water-use evaluation for pepper production under irrigated cultivation in Akure, Nigeria. Global Journal of Science Frontier Research Agriculture \& Biology 12(1):18-22.

Yazar, A., and Ince Kaya, C. 2014. A new crop for salt affected and dry agricultural areas of Turkey: quinoa (Chenopodium quinoa Wild). Turkish Journal of Agricultural and Natural Sciences Special Issue 2:1440-1446.

Zotarelli, L., Dukes, M.D., Scholberg, J.M.S., Femminella, K., and Muñoz-Carpena, R. 2011. Irrigation scheduling for green bell peppers using capacitance soil moisture sensors. Journal of Irrigation and Drainage Engineering 137(2):73-81. 